\title{
Does The Slovak Republic Fulfil European REQUIREMENTS ON RECOGNITION OF FOREIGN Decisions on Custodial Sentences? ${ }^{1}$
}

\author{
Libor Klimek \\ Matej Bel University in Banská Bystrica, Slovak Republic \\ libor.klimek@umb.sk
}

KLIMEK, Libor. Does The Slovak Republic Fulfil European Requirements On Recognition Of Foreign Decisions On Custodial Sentences? International and Comparative Law Review, 2020, vol. 20, no. 2, pp. 215-230. DOI: 10.2478/iclr2020-0025

\begin{abstract}
Summary: Mutual recognition of judicial decisions in criminal matters permits decisions to move from one European State to another. It is a key element for the development of judicial co-operation in criminal matters in the European Union. Its implementation, including recognition of judgments on custodial sentences, was one of the main areas of European Union activity regarding criminal justice. The Slovak Republic has implemented European requirements. The question which begs consideration is whether Slovak national law fulfils such requirements and if they are applicable in Slovak legal practice. The assessment of national implementation of European requirements on recognition of judgments on custodial sentences and its applicability in Slovak legal practice is therefore needed. The paper analyses relevant literature, legislation, case-law and related official documents of the European Union. Moreover, it compares Slovak national law with European requirements. At the outset it briefly assets historical background of the mechanism. In principle, the system works, but there is the possibility for its enhancement..
\end{abstract}

Keywords: criminal justice; mutual recognition; judgment; custodial sentence; Act No. 549/2011 Coll. on the Recognition of Decisions Imposing Criminal Sanction Involving Deprivation of Liberty; Framework Decision 2008/909/JHA on the mutual recognition of custodial sentences

\section{Introduction}

Mutual recognition of judgments on custodial sentences in European territory is ambitious idea. It is a part of the mutual recognition in European criminal law. It permits decisions to move freely from one State to another. It is a key

1 The work was supported by the Scientific Grant Agency of the Ministry of Education, Science, Research and Sport of the Slovak Republic and the Slovak Academy of Sciences (Vedecká grantová agentúra Ministerstva školstva, vedy, výskumu a športu Slovenskej republiky a Slovenskej akadémie vied), grant No. VEGA 1/0004/20 - Implementation of Mutual Recognition of Judicial Decisions in Criminal Matters into the Legal Order of the Slovak Republic. 
element for the development of judicial co-operation in criminal matters in the European Union. Its implementation became one of the main areas of European Union activity regarding criminal justice.

As regards the Slovak Republic, into national law have been implemented special European instruments on mutual recognition governing European requirements addressed to States, including requirements on recognition of judgments on custodial sentences. The question which begs consideration is whether Slovak national law fulfils such requirements and if they are applicable in Slovak legal practice. The objective of the paper is the assessment of national implementation of European requirements on recognition of judgments on custodial sentences and its applicability in Slovak legal practice. The article is not focused on figures, i.e. number of proceedings per year, number of recognised and enforced judgments, etc. Rather, it is focused on practical point of view, i.e. if the mechanism works or does not work, including recommendation to its enhancement.

Much has been written and published on the topic of mutual recognition as a general concept of the European Union. ${ }^{2}$ On the other hand, as far as mutual recognition of judicial decisions is concerned, less has been written and published. ${ }^{3}$ As regards literature focused solely on mutual recognition on judgments on custodial sentences at European level, such publications are available less than a little. ${ }^{4}$ As regards Slovak level and national literature, only a few articles have been published. ${ }^{5}$ These articles are outdated, since they were published at the beginning of application of the mechanism.

2 ARMSTRONG, Kenneth. Mutual Recognition. In BARNARD, Catherine, SCOTT, Joanne (eds.). The Law of the Single European Market: Unpacking the Premises. Hart Publishing: Oxford - Portland, 2002, pp. 225-268; SCHMIDT, Susanne. Mutual Recognition as a New Mode of Governance. Routledge: Oxon - New York, 2008, 174 pages; KERBER, Wolfgang, Van den BERGH, Roger. Mutual Recognition in the Global Trade Regime: Lessons from the EU Experience. In LIANOS, Ioannis, ODUDU, Okeoghene (eds.). Regulating Trade in Services in the EU and the WTO: Trust, Distrust and Economic Integration. New York: Cambridge University Press, 2012, pp. 121-146; JANSSENS, Christine. The Principle of Mutual Recognition in EU Law. New York: Oxford University Press, 2013, 358 pages.

3 KLIMEK, Libor. Mutual Recognition of Judicial Decisions in European Criminal Law. Springer: Cham, 2017, 742 pages.

4 ELLIOT, Victoria. Resource Book on the Transfer of Sentenced Prisoners under EU Framework Decision 909. The Hague: European Organisation of Prison and Correctional Services, Expert Group on Framework Decision 909, 2017.

5 KLIMEK, Libor. Uznávanie a výkon trestných rozsudkov, ktorými sa ukladá sankcia spojená s odňatím slobody v Európskej únii. Justičná revue, 2013, vol. 65, no. 6-7, pp. 944-965; FERENČÍKOVÁ, Simona. Uznávanie a výkon cudzích rozhodnutí v kontexte podmienok výkonu detencie. Štát a právo, 2016, vol. 3, no. 1, pp 81-87. 


\section{European Requirements on Recognition of Foreign Judgments on Cus- todial Sentences}

Probably the first instrument governing cross-border enforcement of custodial sentences in Europe at inter-state level was the Treaty between Belgium, The Netherlands and Luxembourg on the Enforcement of Judgments in Criminal Matters $^{6}$ of 1968 (also known as the Benelux Treaty). The Treaty concerned the enforcement of judgments in criminal matters between the Benelux countries, i. e. between contracting States. The Treaty provided that a sentence passed in a contracting State may be enforced in another contracting State only if the conduct is an offence also in the second contracting State or it is on a list produced in accordance with the Treaty. The Treaty could have been a local success, however, it has never entered into force.

The Council of Europe has pioneered the use of conventions which may impact on the release of prisoners sentenced for crimes committed outside their home countries. ${ }^{7}$ The first instrument governing cross-border enforcement of custodial sentences at European level was the European Convention on the International Validity of Criminal Judgments of 1970. Further, in 1983 was adopted the Convention on the Transfer of Sentenced Persons ${ }^{8}$. The later Convention enabled further development for States to enforce the judgments of another State; the Additional Protocol to that Convention', which allows transfer without the person's consent, subject to certain conditions, was adopted in 1997, but it has not been ratified by all European States.

In 1991 a group of Member States of the European Communities (today the European Union) signed the Convention on the Enforcement of Foreign Criminal Sentences ${ }^{10}$. In relations between Member States which are parties to the abovementioned European Convention on the International Validity of Criminal Judgments of 1970, the Convention was to apply to the extent that it supplements the provisions of that Convention or facilitates the application of the principles contained therein. According to this Convention, the Member States of the European Communities undertake to accord each other the widest possible co-operation with regard to the transfer of enforcement of sentences. Since

6 Treaty of $26^{\text {th }}$ September 1968 between Belgium, The Netherlands and Luxembourg on the Enforcement of Judgments in Criminal Matters.

7 Van ZYL, Dirk, SPENCER, John. The European Dimension to the Release of Sentenced Prisoners. In PADFIELD, Nicola, Van ZYL, Dirk, DÜNKEL, Frieder (eds.). Release from Prison: European Policy and Practice. Cullompton: Willan Publishing, 2013, pp. 21-22.

8 Convention on the Transfer of Sentenced Persons. Council of Europe, European Treaty Series No. 112 [1983], Strasbourg, 21 $1^{\text {st }}$ March 1983.

9 Additional Protocol to the Convention on the Transfer of Sentenced Persons. Council of Europe, European Treaty Series No. 167 [1997], Strasbourg, $18^{\text {th }}$ December 1997.

10 Convention between the Member States of the European Communities on the Enforcement of Foreign Criminal Sentences. Brussels, $13^{\text {th }}$ November 1991. 
the Convention has never been ratified by any of the Member States, it has never entered into force.

Abovementioned measures based on international law, in principle, have never became fully efficient in legal practice. As a complex of international (European) standards on recognition of foreign decisions on custodial sentences, they are complicated.

At the European Union level was introduced newer alternative of understanding of recognition of judgments on custodial sentences (and measures involving deprivation of liberty) - the Framework Decision 2008/909/JHA on the application of the principle of mutual recognition to judgments in criminal matters imposing custodial sentences or measures involving deprivation of liberty for the purpose of their enforcement in the European Union" (hereinafter the "Framework Decision 2008/909/JHA on the mutual recognition of custodial sentences", or the "Framework Decision"). De Wree and Balcaen consider it as an important action undertaken by the European Union. ${ }^{12}$ The objective of the Framework Decision is not defined in its text. However, its objective is to extend the principle of mutual recognition between Member States of the European Union to judgements in criminal matters that impose a custodial sentence or a measure involving the deprivation of liberty. On the one hand, the Framework Decision allows a Member State of the European Union to execute a prison sentence issued by another Member State against a person who remains in the first Member State. On the other hand, it establishes a system for transferring convicted prisoners back to the Member State of nationality or habitual residence (or to another Member State with which they have close ties) to serve their prison sentence.

The social rehabilitation is the underlying objective of the Framework Decision 2008/909/JHA on the mutual recognition of custodial sentences and it should be applied accordingly in practice. Nevertheless, there are various practical problems. There is a difference in the amount of effort made by some Member States in assessing whether a transfer would be appropriate. The Netherlands, for example, make use of probation officers. These volunteers visit prisoners abroad, provide support and begin the process by assessing the prisoners. Their information is then used to assess whether rehabilitation in The Netherlands or another State is appropriate. There also raises the question whether and how the accuracy of the sentenced person's representations should be checked. They

11 Council Framework Decision 2008/909/JHA of $27^{\text {th }}$ November 2008 on the application of the principle of mutual recognition to judgments in criminal matters imposing custodial sentences or measures involving deprivation of liberty for the purpose of their enforcement in the European Union as amended by the Framework Decision 2009/299/JHA. Official Journal of the European Union, L 327/27 of $5^{\text {th }}$ December 2008.

12 De WREE, Eveline, BALCAEN, Annelies. Punishment Across Borders: The Rationales Behind International Execution of Sentences. In COOLS, Marc (ed.). Readings on Criminal Justice, Criminal Law \& Policing. Antwerpen - Apeldoorn: Maklu, 2009, pp. 25-65. 
agree that a decision is especially hard to make if there is no immediate link with the executing Member State apart from the nationality. This raises the question to what extent a sentenced person can lose the right to return to the country of nationality. ${ }^{13}$

Further, there is a risk that the Framework Decision 2008/909/JHA on the mutual recognition of custodial sentences will be used as an instrument by which foreign prisoners with European Union nationality can be routinely sent back to their country of origin. Although such an interpretation would not automatically imply that rehabilitation would fail, it could lead to a conflict of interest with the Member States who will be required to accept large numbers of prisoners. This could potentially result in a request for clarification of the Framework Decision's requirements being sought before a court or tribunal in a Member State and, ultimately, before the Court of Justice of the European Union. ${ }^{14}$

The Framework Decision 2008/909/JHA on the mutual recognition of custodial sentences is based on the principle of mutual recognition, which is repeatedly seen as a cornerstone of judicial co-operation in criminal matters within the European Union. ${ }^{15}$ It should be noted that in the European Union the Framework Decision 2008/909/JHA on the mutual recognition of custodial sentences is not the only mutual recognition instrument in criminal matters. There is no need to introduce their in-depth analysis, however, the relationship of the Framework Decision 2008/909/JHA on the mutual recognition of custodial sentences with the Framework Decision 2008/947/JHA on mutual recognition of

13 European Organisation of Prison and Correctional Services. Working Group Report. Expert Group on Framework Decision 909, 2013.

14 European Organisation of Prison and Correctional Services. Working Group Report. Expert Group on Framework Decision 909, 2013.

15 For example: Commission of the European Communities: Mutual recognition in the context of the follow-up to the Action Plan for the Single Market. Communication from the Commission to the Council and the European Parliament, COM(1999) 299 final, p. 2; Commission of the European Communities: Mutual Recognition of Final Decisions in Criminal Matters. Communication from the Commission to the Council and the European Parliament, COM(1999) 495 final, p. 3; Judgment of the Court of Justice of the European Communities of $3^{\text {rd }}$ May 2007 in case C-303/05 - Advocaten voor de Wereld VZW $v$ Leden van de Ministerraadi, para. 4; Judgment of the Court of Justice of the European Communities of $1^{\text {st }}$ December 2008 in case C-388/08 PPU -Artur Leymann and Aleksei Pustovarov, para. 49; Judgment of the Court of Justice of the European Union of $28^{\text {th }}$ June 2012 in case C-192/12 PPU - Melvin West, para. 49; Judgment of the Court of Justice of the European Union of $5^{\text {th }}$ September 2012 in case C-42/11 - João Pedro Lopes Da Silva Jorge, para. 6; Judgment of the Court of Justice of the European Union of $29^{\text {th }}$ January 2013 in case C-396/11 - Ciprian Vasile Radu, para. 6; Judgment of the Court of Justice of the European Union of $30^{\text {th }}$ May 2013 in case C-168/13 PPU - Jeremy F v Premier minister, para. 36.

Published by Palacký University Olomouc, Czech Republic, 2020.

ISSN (print): 1213-8770; ISSN (online): 2464-6601 
probation measures and alternative sanction $\mathrm{s}^{16}$ should be explained. Although they were adopted on the same date and although they both aim at facilitating the social rehabilitation of sentenced persons, the Framework Decision 2008/909/JHA differs in various ways from the Framework Decision 2008/947/ JHA. The resulting differences in national implementation legislation could pose practical problems when combining the application of both Framework Decisions. A judgment contains occasionally a sentence which is partly custodial and partly suspended (with or without probation). As a result, the situation could arise where a Member State could be asked to execute the sentence both under the Framework Decision 2008/909/JHA and the Framework Decision 2008/947/ JHA. Depending on the fact whether the executing State would have made a specific refusal ground mandatory or optional within its national legislation, the combined application of both framework decisions could result in a situation where only a part of the sentence could be transferred. Further, the States discussed this issue and recognise the potential problems arising from a transfer of a combined sentence. This would be considered on a case-by-case basis.

Framework decisions of the European Union are binding upon its Member States as to the result to be achieved, but they leave national legislative authorities to choose the form and methods of their implementation.

The Member States of the European Union shall take the necessary measures to comply with the provisions of the Framework Decision 2008/909/JHA on the mutual recognition of custodial sentences by $5^{\text {th }}$ December 2011. Only five States fulfilled that deadline, namely Denmark, Italy, Finland, Luxembourg and the United Kingdom. Some States implemented the Framework Decision in 2012 and 2013, for example France, Hungary, The Netherlands and Poland. Some States even later. ${ }^{17}$ The expert group of the European Organisation of Prison and Correctional Services argues that the slow implementation is in clear contrast

16 Council Framework Decision 2008/947/JHA of $27^{\text {th }}$ November 2008 on the application of the principle of mutual recognition to judgments and probation decisions with a view to the supervision of probation measures and alternative sanctions as amended by the Framework Decision 2009/299/JHA. Official Journal of the European Union, L 337/102 of $16^{\text {th }}$ December 2008.

17 European Commission: Tables State of play and Declarations accompanying the document Report from the Commission to the European Parliament and the Council on the implementation by the Member States of the Framework Decisions 2008/909/JHA, 2008/947/JHA and 2009/829/JHA on the mutual recognition of judicial decisions on custodial sentences or measures involving deprivation of liberty, on probation decisions and alternative sanctions and on supervision measures as an alternative to provisional detention. Commission staff working document, SWD(2014) 34 final; Council of the European Union: Implementation of the Council Framework Decision 2008/909/JHA on the application of the principle of mutual recognition to judgments in criminal matters imposing custodial sentences or measures involving deprivation of liberty for the purpose of their enforcement in the European Union, 9618/1/14, REV 1. 
with the prioritisation of the theme of prisoner transfer at the political level in some Member States. ${ }^{18}$

As regards the method of implementation of the Framework Decision in the Member States of the European Union, it does not vary considerably. In principle, two methods can be observed, first, adoption of an amendment in order to supplement and "update" earlier existing legislation in the area of procedural criminal law, and second, adoption of an entirely new legislation.

In general, as pointed out the European Commission, the level of implementation of the Framework Decision 2008/909/JHA on the mutual recognition of custodial sentences is far from satisfactory. The partial and incomplete transposition of the Framework Decision hampers the application of the principle of mutual recognition in the area of criminal justice. ${ }^{19}$ The question which begs consideration is the implementation of the Framework Decision 2008/909/JHA on the mutual recognition of custodial sentences in the Slovak Republic, including assessment of legal practice in this field.

\section{Implementation in the Slovak Republic and Slovak Legal Practice}

There is no need to analyse national criminal law of the Slovak Republic. We can briefly declare that is has European (continental) traditions. Criminal justice as part of criminal law is an important element of the national legal order of the Slovak Republic, the purpose of which is to ensure the protection of society against the most serious offenses. ${ }^{20}$ Slovak criminal law and its criminal justice have been evolved into modern system of legislation and case-law accepting European standards in this area. It should be noted, on the other hand, that even this system of legislation and case-law has been evolved, there are cases when it fails.

To fulfil European requirements, as they are defined by the Framework Decision 2008/909/JHA on the mutual recognition of custodial sentences, the Slovak Republic adopted a new legislation - the Act No. 549/2011 Coll. on the Recognition and Enforcement of Decisions Imposing Criminal Sanction Involving Dep-

18 European Organisation of Prison and Correctional Services. Working Group Report. Expert Group on Framework Decision 909, 2013.

19 European Commission: Tables State of play and Declarations accompanying the document Report from the Commission to the European Parliament and the Council on the implementation by the Member States of the Framework Decisions 2008/909/JHA, 2008/947/JHA and 2009/829/JHA on the mutual recognition of judicial decisions on custodial sentences or measures involving deprivation of liberty, on probation decisions and alternative sanctions and on supervision measures as an alternative to provisional detention. Commission staff working document, SWD(2014) 34 final.

20 ŠRAMEL, Bystrík, MACHYNIAK, Ján, GUŤAN, Dušan. Slovak Criminal Justice and the Philosophy of Its Privatization: An Appropriate Solution of Problems of Slovak Justice in the $21^{\text {st }}$ Century? Social Sciences, 2020, Vol. 9, pp. 1-12. 
rivation of Liberty in the European Union" ${ }^{21}$ (hereinafter the "Act No. 549/2011 Coll. on the Recognition of Decisions Imposing Criminal Sanction Involving Deprivation of Liberty" or the "Act"). In relation to the Slovak Code of Criminal Proceedings, this Act is a special legislation applicable in special criminal matters. $^{22}$ This relationship has been accepted and confirmed by legal practice, in particular by the Supreme Court of the Slovak Republic. ${ }^{23}$ Indeed, as regards the very first requirement addressed to all Member states of the European union - to implement the Framework Decision 2008/909/JHA on the mutual recognition of custodial sentences into national law - the Slovak Republic fulfilled it. Besides the Act No. 549/2011 Coll. on the Recognition of Decisions Imposing Criminal Sanction Involving Deprivation of Liberty was adopted similar national law - the Act No. 533/2011 Coll. on the Recognition and Enforcement of Judgments Imposing Penal Sanction Not Involving Deprivation of Liberty or Probation Measures with a View to the Supervision in the European Union ${ }^{24}$. This Act regulates similar subject matter, however, its scope of application is focused on judgments imposing penal sanction not involving deprivation of liberty. This Act is a result of the implementation of the Framework Decision 2008/947/JHA on mutual recognition of probation measures and alternative sanctions into the national law of the Slovak Republic (see above).

The Act No. 549/2011 Coll. on the Recognition of Decisions Imposing Criminal Sanction Involving Deprivation of Liberty regulates the procedure of competent Slovak authorities in two scenarios: first, in case of the transmission of a decision imposing a custodial sentence issued by a Slovak national court in

21 Full official name - the Act of the National Council of the Slovak Republic of $2^{\text {nd }}$ December 2011 No. 549/2011 Coll. on the Recognition and Enforcement of Decisions Imposing Criminal Sanction Involving Deprivation of Liberty in the European Union as amended by later legislation [Slovak: zákon Národnej rady Slovenskej republiky z 2. decembra 2011 č. 549/2011 Z. z. o uznávaní a výkone rozhodnutí, ktorými sa ukladá trestná sankcia spojená s odňatím slobody v Európskej únii v znení neskorších predpisov].

22 Article 29 of the Act No. 549/2011 Coll. on the Recognition of Decisions Imposing Criminal Sanction Involving Deprivation of Liberty.

23 Resolution of the Supreme Court of the Slovak Republic of $4^{\text {th }}$ November 2015, Ref. No. 3 Urto 5/2015; Judgment of the Supreme Court of the Slovak Republic of $21^{\text {st }}$ April 2016, Ref. No. 6 Urto 1/2016; Judgment of the Supreme Court of the Slovak Republic of $15^{\text {th }}$ February 2017, Ref. No. 3 Urto 2/2017; Judgment of the Supreme Court of the Slovak Republic of $13^{\text {th }}$ December 2017, Ref. No. 3 Urto 8/2017; Resolution of the Supreme Court of the Slovak Republic of $13^{\text {th }}$ November 2019, Ref. No. 6 Urto 7/2019.

24 Full official name - Act of the National Council of the Slovak Republic of $2^{\text {nd }}$ December 2011 No. 533/2011 Coll. on the Recognition and Enforcement of Judgments Imposing Penal Sanction Not Involving Deprivation of Liberty or Probation Measures with a View to the Supervision in the European Union [Slovak: zákon Národnej rady Slovenskej republiky z 2. decembra 2011 č. 533/2011 Z. z. o uznávaní a výkone rozhodnutí, ktorými sa ukladá trestná sankcia nespojená s odňatím slobody alebo probačné opatrenie na účely dohladu v Európskej únii]. 
criminal proceedings for its recognition and enforcement in another Member State of the European Union in order to facilitate the social rehabilitation of the sentenced person, and, second, in case of the recognition and enforcement of a decision issued in criminal proceedings by a court of any other Member State of the European Union. ${ }^{25}$ Both scenarios - i.e. transmission of a Slovak judgment as well as recognition of a foreign judgment - is applicable only in relation to a State which has implemented into its national law the Framework Decision 2008/909/ JHA on the mutual recognition of custodial sentences into national law. It is natural since the mechanism in the Slovak legal practice requires application of the same European requirements in any other State. Legal practice reveals that Slovak authorities co-operate, in particular, with authorities of the Czech Republic and Austria, less often with authorities of other Member States of the European Union, for example, Croatia, Hungary and Germany. Its natural since many citizens of the Slovak Republic live and/or work in the Czech Republic and in Austria.

As regards recognition of foreign judgment on custodial sentence and its enforcement in the Slovak Republic, the Constitutional Court of the Slovak Republic argues that the purpose of the recognition of a foreign decision is its acceptance by the Slovak Republic. Its purpose is not to replace foreign decision with a new decision, because a foreign decision has already ruled on the guilt and punishment of the person. Therefore, no evidence of the facts of the "foreign case" shall be taken. Slovak authorities shall check only conditions for recognition of a foreign decision, i. e. if they are met according to Slovak national legislation stipulated in the Act No. 549/2011 Coll. on the Recognition of Decisions Imposing Criminal Sanction Involving Deprivation of Liberty. ${ }^{26}$ Similar opinion was introduced by the Supreme Court of the Slovak Republic. ${ }^{27}$

Two scenarios are possible. First, the double criminality requirement shall apply. The Act No. 549/2011 Coll. on the Recognition of Decisions Imposing Criminal Sanction Involving Deprivation of Liberty stipulates that a foreign decision may be recognised and enforced in the Slovak Republic if the offence for which the decision was issued is also a criminal offense under the law of the Slovak Republic, and if: ${ }^{28}$

- the sentenced person is a citizen of the Slovak Republic and he/she has his/her habitual residence in the territory of the Slovak Republic, or

25 Article 1 of the Act No. 549/2011 Coll. on the Recognition of Decisions Imposing Criminal Sanction Involving Deprivation of Liberty.

26 Resolution of the Constitutional Court of the Slovak Republic of $6^{\text {th }}$ October 2015, Ref. No. III. ÚS 498/2015.

27 Judgment of the Supreme Court of the Slovak Republic of $13^{\text {th }}$ January 2017, Ref. No. 2 Urto $10 / 2016$.

28 Article 2 of the Act No. 549/2011 Coll. on the Recognition of Decisions Imposing Criminal Sanction Involving Deprivation of Liberty. 
- the sentenced person is a citizen of the Slovak Republic, he/she does not have his habitual residence in the territory of the Slovak Republic, but after serving his/her sanction associated with imprisonment he/she shall be deported in the territory of the Slovak Republic, or

- the sentenced person is staying in the territory of the Slovak Republic or in the territory of any other Member State of the European Union and a Slovak court agrees to take a decision on its recognition and enforcement in the Slovak Republic at the request of the competent authority of other Member State of the European Union.

In such instance, the Slovak Republic as executing State impose the dual criminality requirement of the offence committed by the sentenced person.

However, on the other hand, the double criminality of 32 categories of offences is not checked by in the Slovak Republic. There is no need to analyse all categories of offences where the partial removal of the double criminality requirement is applicable. Such categories of offences are, for example, trafficking in human beings, corruption, computer-related crime, racism and xenophobia.

As regards European level, under the Framework Decision 2008/909/JHA on the mutual recognition of custodial sentences the procedure is the same - two scenarios are possible. First, the Framework Decision stipulates that the executing State may make the recognition of the judgment and enforcement of the sentence subject to the condition that it relates to acts which also constitute an offence under the law of the executing State, whatever its constituent elements or however it is described. ${ }^{29}$ In such instances, the executing State may impose the dual criminality requirement. Second, the double criminality of 32 categories of offences is not checked by the judicial authority of the executing Member State which is competent to execute the decision on custodial sentence or measure involving deprivation of liberty. Indeed, the Slovak legislation fulfil this European requirement.

Direct communication between national authorities States is another requirement of the Framework Decision 2008/909/JHA on the mutual recognition of custodial sentences. In comparison to former mechanism (mechanism prior the Framework Decision), government approval or central authority approval is no longer required in case of mutual recognition measures. Mutual recognition procedures allow direct communication between competent national authorities. In particular the judges and the public prosecutors became sole competent authorities in the mutual recognition procedures. As all mutual recognition instruments, the Framework Decision 2008/909/JHA on the mutual recognition of custodial sentences aims at a quicker and simpler procedure than traditional co-operation in criminal matters. Hence it stipulates as a general rule the direct

29 Article 7(3) of the Framework Decision 2008/909/JHA on the mutual recognition of custodial sentences. 
communication between national authorities of the Member States. Accordingly, the competent authority of the issuing State should transmit the decision direct$l y$ to the competent authority of the executing State. The Framework Decision stipulates that all official communications shall be made directly between competent authorities..$^{30}$ Moreover, the decision shall be forwarded by the competent authority of the issuing State directly to the competent authority of the executing State. ${ }^{31}$ As regard Slovak context, the Act No. 549/2011 Coll. on the Recognition of Decisions Imposing Criminal Sanction Involving Deprivation of Liberty stipulates that courts as competent authorities in procedure shall communicate directly with the judicial authorities of all Member States of the European Union (emphasis added). ${ }^{32}$

Under the Framework Decision 2008/909/JHA on the mutual recognition of custodial sentences the judgment (or a certified copy of it) together with its certificate shall be forwarded by the competent authority of the issuing State directly to the competent authority of the executing State. The Framework Decision introduced a form appended to its core text. The intention was to implement a working tool that might easily be filled in by the issuing judicial authorities and recognised by the executing judicial authorities. This follows the Act No. 549/2011 Coll. on the Recognition of Decisions Imposing Criminal Sanction Involving Deprivation of Liberty. It contains a form of the certificate of the judgment. As regard foreign judgment, Slovak national authorities shall accept it if, first, the judgment is supplemented by its certificate and, second, if all needed information is set in the certificate. As far as language is concerned, the certificate shall be translated into the official language of the Slovak Republic - i.e. Slovak language. The translation of the judgment is not needed. As regards the cooperation with the Czech Republic, translation of the certificate is not needed, since Slovak language and Czech language are very similar.

In general, European Union legislation on mutual recognition in criminal matters is focused on mutually recognised decisions in a single European judicial area. Their recognition can be refused only in respect of European grounds in line with the legislation of the European Union. While the system established by the Framework Decision 2008/909/JHA on the mutual recognition of custodial sentences is based on the principle of mutual recognition, that recognition does not mean that there is an absolute obligation to recognise and execute the judgment on custodial sentence which has been transmitted. The Framework Decision includes optional grounds for non-recognition and non- enforcement the decision. Thus, the competent authorities of the executing State are in prin-

30 Article 5(3) of the Framework Decision 2008/909/JHA on the mutual recognition of custodial sentences.

31 Article 5(1) of the Framework Decision 2008/909/JHA on the mutual recognition of custodial sentences.

32 Article 22(1) of the Act No. 549/2011 Coll. on the Recognition of Decisions Imposing Criminal Sanction Involving Deprivation of Liberty. 
ciple obliged to act, unless they decide to invoke one of the grounds for nonrecognition or non- enforcement of the decision provided for in the Framework Decision. The Act No. 549/2011 Coll. on the Recognition of Decisions Imposing Criminal Sanction Involving Deprivation of Liberty stipulates that the competent authority may refuse to recognise the judgment and enforce the sentence, for example, if the principle of ne bis in idem is applicable, if the sentenced person due to his/her age is not criminally liable according to national law of the Slovak Republic for the offence for which the judgment was taken, or if less than six months of the sentence remain to be served. In principle, such national law rules follow the requirements of the Framework Decision.

There are many requirements introduced by the Framework Decision 2008/909/JHA on the mutual recognition of custodial sentences. Last, but not least, the rule of speciality should be assessed. The general idea of the rule of speciality in case of the mutual recognition of custodial sentences is based on the rule that a person transferred to the executing State shall not be prosecuted, sentenced or otherwise deprived of his/her liberty for an offence committed before his/her transfer other than that for which he or she was transferred. ${ }^{33}$ Similarly to the European arrest warrant and the surrender procedure this rule is linked to the sovereignty of the executing State. It should be noted that the rule of specialty applies only where the person has been transferred to the executing State. It should therefore not be applicable where the person has not been transferred to the executing State, for example, where the person has fled to the executing State. The Act No. 549/2011 Coll. on the Recognition of Decisions Imposing Criminal Sanction Involving Deprivation of Liberty stipulates that a sentenced person transferred from another Member State of the European Union to serve a criminal sanction in the Slovak Republic may not be prosecuted and convicted for another offense for which he/she was transmitted to the Slovak Republic. ${ }^{34}$ The Supreme Court of the Slovak Republic argues that the rule of specialty serves to protect a person who has been transferred from the jurisdiction of the requested State. ${ }^{35}$ In principle, it is a right of the sentenced person.

Of course, the general idea of the rule of speciality shall not apply in special situations, for example, in the following cases: ${ }^{36}$

33 Article 18(1) of the Framework Decision 2008/909/JHA on the mutual recognition of custodial sentences.

34 Article 21(1) of the Act No. 549/2011 Coll. on the Recognition of Decisions Imposing Criminal Sanction Involving Deprivation of Liberty.

35 Resolution of the Supreme Court of the Slovak Republic of $3^{\text {rd }}$ December 2014, Ref. No. 3 Urto 8/2014.

36 Article 18(2) of the Framework Decision 2008/909/JHA on the mutual recognition of custodial sentences, Article 21(2) of the Act No. 549/2011 Coll. on the Recognition of Decisions Imposing Criminal Sanction Involving Deprivation of Liberty. 
- when the person having had an opportunity to leave the territory of the Slovak Republic has not done so within 45 days of his/her final discharge, or has returned to that territory after leaving it,

- when the criminal proceedings does not give rise to the application of a measure restricting personal liberty,

- when the person consented to the transfer,

- when the sentenced person, after his/her transfer, has expressly renounced entitlement to the rule of speciality with regard to specific offences preceding his/her transfer.

It should be noted that the rule of speciality is one of the most problematic procedural issues of the procedure, i.e. procedure on recognition and enforcement of the judgment. The wording of the legislation is not clear and therefore the interpretation of relevant legal provisions on the rule of speciality causes its vague understanding. In comparison to European arrest warrant proceeding, several references for a preliminary ruling have been submitted to the Court of Justice of the European Union.

\section{Lex Ferenda}

As seen, as for the most important issues, Slovak national law on mutual recognition of foreign judgments on custodial sentences regulated by the Act No. 549/2011 Coll. on the Recognition of Decisions Imposing Criminal Sanction Involving Deprivation of Liberty fulfils European requirements as defined by the Framework Decision 2008/909/JHA on the mutual recognition of custodial sentences. On the other hand, it does not mean that there are no practical problems.

We are the opinion that the adoption of special laws (national Acts) implementing mutual recognition of judicial decisions in criminal matters in the Slovak Republic is not appropriate method for their implementation, including the Act No. 549/2011 Coll. on the Recognition of Decisions Imposing Criminal Sanction Involving Deprivation of Liberty. We are the opinion that all mutual recognition instruments, including the recognition and enforcement of decisions on custodial sentences, should be regulated by a single comprehensive law. In Slovak national law there is a legislative tradition of Slovak criminal law as a codified branch of national law in codes - in particular the Criminal Code and the Code of Criminal Proceedings. ${ }^{37}$ As regards procedural criminal law, the most important law is the Code on Criminal Proceedings. Gradual adoption of procedural laws on mutual recognition of judicial decisions causes fragmenta-

37 Mentioned codes are not the only national acts regulating national criminal law. In addition to them, many "less important" acts are applicable, for example, the Act. No. 757/2004 Coll. on Courts, the Act No. 153/2001 Coll. on the Prosecution Service, the Act No. 171/1993 Coll. on the Police Force, the Act No. 586/2003 Coll. on Advocacy (all as amended by later legislation). 
tion of national legislation regulating criminal proceedings. Indeed, it cased that the national law on criminal proceedings is confusing.

It is desirable to accept the fact that criminal proceedings has been influenced by European elements, which are, among others, instruments on mutual recognition of judicial decisions. At present, special laws of mutual recognition are perceived as "ancillary Acts" in addition to the Code on Criminal Proceedings. This is not appropriate approach of national legislator. At least three alternatives of new approach are possible.

The first alternative is the adoption of a new legislation governing all mutual recognition of judicial decisions in criminal matters in the European Union. As a consequence, all special laws on mutual recognition, including the Act No. 549/2011 Coll. on the Recognition of Decisions Imposing Criminal Sanction Involving Deprivation of Liberty, shall be replaced and repealed by a new legislation. The second alternative is the adoption of a new legislation governing all area of co-operation in criminal matters within the European Union. The third alternative is the adoption of the new legislation - procedural code governing legal relations with foreign countries in criminal matters, including all co-operation in the European Union.

\section{Conclusion}

At the European Union level was introduced newer alternative of understanding of recognition of custodial sentences (and measures involving deprivation of liberty) - the Framework Decision 2008/909/JHA on the mutual recognition of custodial sentences. Framework decisions of the European Union are binding upon its Member States as to the result to be achieved, but they leave national legislative authorities to choose the form and methods of their implementation. As regards the Slovak Republic, into national law have been implemented special European instruments on mutual recognition governing European requirements, including requirements on recognition of judgments on custodial sentences. To fulfil these requirements the Slovak Republic adopted a new legislation - the Act No. 549/2011 Coll. on the Recognition of Decisions Imposing Criminal Sanction Involving Deprivation of Liberty. This Act regulates the procedure of competent Slovak authorities in two scenarios: first, in case of the transmission of a decision imposing a custodial sentence issued by a Slovak national court in criminal proceedings for its recognition and enforcement in another Member State of the European Union in order to facilitate the social rehabilitation of the sentenced person, and, second, in case of the recognition and enforcement of a decision issued in criminal proceedings by a court of any other Member State of the European Union.

As for the most important issues, Slovak national law on mutual recognition of foreign judgments on custodial sentences regulated by the Act No. 549/2011 
Coll. on the Recognition of Decisions Imposing Criminal Sanction Involving Deprivation of Liberty fulfils European requirements as defined by the Framework Decision 2008/909/JHA on the mutual recognition of custodial sentences. On the other hand, it does not mean that there are no practical problems. It is desirable to accept the fact that criminal proceedings has been influenced by European elements, which are, among others, instruments on mutual recognition of judicial decisions. At present, special laws of mutual recognition are perceived as "ancillary Acts" in addition to the Code on Criminal Proceedings. This is not appropriate approach. We recommend to national legislator to adopt new legislation regulating mutual recognition of judgments on custodial sentences. There are at least three alternatives.

\section{List of references}

Act of the National Council of the Slovak Republic of $2^{\text {nd }}$ December 2011 No. 533/2011 Coll. on the Recognition and Enforcement of Judgments Imposing Penal Sanction Not Involving Deprivation of Liberty or Probation Measures with a View to the Supervision in the European Union.

Act of the National Council of the Slovak Republic of $2^{\text {nd }}$ December 2011 No. 549/2011 Coll. on the Recognition and Enforcement of Decisions Imposing Criminal Sanction Involving Deprivation of Liberty in the European Union as amended by later legislation.

Council Framework Decision 2008/909/JHA of $27^{\text {th }}$ November 2008 on the application of the principle of mutual recognition to judgments in criminal matters imposing custodial sentences or measures involving deprivation of liberty for the purpose of their enforcement in the European Union as amended by the Framework Decision 2009/299/JHA. Official Journal of the European Union, L 327/27 of $5^{\text {th }}$ December 2008.

Council Framework Decision 2008/947/JHA of $27^{\text {th }}$ November 2008 on the application of the principle of mutual recognition to judgments and probation decisions with a view to the supervision of probation measures and alternative sanctions as amended by the Framework Decision 2009/299/JHA. Official Journal of the European Union, L $337 / 102$ of $16^{\text {th }}$ December 2008.

Council of the European Union: Implementation of the Council Framework Decision 2008/909/JHA on the application of the principle of mutual recognition to judgments in criminal matters imposing custodial sentences or measures involving deprivation of liberty for the purpose of their enforcement in the European Union, 9618/1/14, REV 1.

De WREE, Eveline, BALCAEN, Annelies. Punishment Across Borders: The Rationales Behind International Execution of Sentences. In COOLS, Marc (ed.). Readings on Criminal Justice, Criminal Law \& Policing. Antwerpen - Apeldoorn: Maklu, 2009, pp. 25-65.

ELLIOT, Victoria. Resource Book on the Transfer of Sentenced Prisoners under EU Framework Decision 909. The Hague: European Organisation of Prison and Correctional Services, Expert Group on Framework Decision 909, 2017.

European Commission: Tables State of play and Declarations accompanying the document Report from the Commission to the European Parliament and the Council on the implementation by the Member States of the Framework Decisions 2008/909/JHA, 2008/947/ 
JHA and 2009/829/JHA on the mutual recognition of judicial decisions on custodial sentences or measures involving deprivation of liberty, on probation decisions and alternative sanctions and on supervision measures as an alternative to provisional detention. Commission staff working document, SWD(2014) 34 final.

European Organisation of Prison and Correctional Services. Working Group Report. Expert Group on Framework Decision 909, 2013.

Judgment of the Supreme Court of the Slovak Republic of 21 $1^{\text {st }}$ April 2016, Ref. No. 6 Urto $1 / 2016$.

Judgment of the Supreme Court of the Slovak Republic of $13^{\text {th }}$ December 2017, Ref. No. 3 Urto 8/2017.

Judgment of the Supreme Court of the Slovak Republic of $13^{\text {th }}$ January 2017, Ref. No. 2 Urto $10 / 2016$.

Judgment of the Supreme Court of the Slovak Republic of $15^{\text {th }}$ February 2017, Ref. No. 3 Urto $2 / 2017$.

KLIMEK, Libor. Mutual Recognition of Judicial Decisions in European Criminal Law. Springer: Cham, 2017, 742 pages.

Resolution of the Supreme Court of the Slovak Republic of $3^{\text {rd }}$ December 2014, Ref. No. 3 Urto 8/2014.

Resolution of the Constitutional Court of the Slovak Republic of $6^{\text {th }}$ October 2015, Ref. No. III. ÚS 498/2015.

Resolution of the Supreme Court of the Slovak Republic of $4^{\text {th }}$ November 2015, Ref. No. 3 Urto 5/2015.

Resolution of the Supreme Court of the Slovak Republic of $13^{\text {th }}$ November 2019, Ref. No. 6 Urto 7/2019.

ŠRAMEL, Bystrík, MACHYNIAK, Ján, GUŤAN, Dušan. Slovak Criminal Justice and the Philosophy of Its Privatization: An Appropriate Solution of Problems of Slovak Justice in the $21^{\text {st }}$ Century? Social Sciences, 2020, Vol. 9, pp. 1-12.

Van ZYL, Dirk, SPENCER, John. The European Dimension to the Release of Sentenced Prisoners. In PADFIELD, Nicola, Van ZYL, Dirk, DÜNKEL, Frieder (eds.). Release from Prison: European Policy and Practice. Cullompton: Willan Publishing, 2013, pp. 9-46. 